\title{
The Effect of Group Counseling Services on Self- Confidence in Learning English of Primary School Students in Covid-19 Pandemic
}

\author{
Nur Dahniar ${ }^{1}$, Muhammad Musafir ${ }^{2}$ \\ \{nurdahniar.umb@gmail.com $\left.{ }^{1}\right\}$ \\ Department of Primary School Teacher Education, Universitas Muhammadiyah Buton, \\ Baubau, Indonesia ${ }^{1}$ \\ Post-Graduate student of Guidance and Counseling Program, Universitas Negeri Yogyakarta, \\ Yogyakarta, Indonesia ${ }^{2}$
}

\begin{abstract}
The Covid-19 situation has a major impact on all elements of life, including education. The learning process changes, from face-to-face in class to virtual face-to-face. In addition, the approach taken has also changed. Similar to learning English in elementary schools, the application of the group counseling approach is to maintain and increase the self-confidence of elementary school students in learning English during the Covid-19 pandemic situation so that it stays true. To find out the perspective both of students and parents about the group counseling approach to increase students' confidence in learning English during the Covid-19. This research used qualitative methodology within a case study design. This research shows that the students have positive attitudes towards the use of a group counseling approach to increase students' confidence in learning English during the Covid-19 pandemic. The implication of this research is to provide student's perception into the use of group counseling approach to increase students' confidence in learning English during the Covid-19 pandemic in the primary education setting, the findings of this study offer several recommendations for Indonesian policymakers and future researchers.
\end{abstract}

Keywords: Group counseling, self-confident, english learning

\section{Introduction}

Humans are social creatures that cannot live alone, develop from prenatal, infancy, early childhood, middle and, late childhood, adolescence, early adulthood, middle adulthood, and late adulthood. Childhood is a phase where children experience changes in their emotions, bodies, interests, behavior patterns, self-confidence, and are also full of problems related to themselves, related to God and, the social environment.

Individual belief in themselves, both children and adults arise because they have selfconfidence. Self-confidence is part of the development of one's personality as determinants of one's attitude and behavior as a determinant of their success in learning. Lauster revealed that the nature of self-confidence is not a trait inherited from life experience, and can be taught and instilled through education so that certain efforts can be made to form and increase selfconfidence. By developing through the learning process in their environment. 
Gufron [3] defines that group counseling is a type of group activity that provides counseling services to two or more counselees to deal with adaptation problems and developmental problems. The process of assistance provided by the counselor (group leader) to several counselees (group members) through a group atmosphere to help them both prevent and problem-solving so that they can change their behavior to achieve optimal development in the areas of personal, social, academic life. and their careers. High self-confidence will develop a strong personality in a person, reduce stress and, are not easily affected by threatening situations. In contrast to individuals with low self-efficacy will tend and do not want to try or like cooperation in difficult situations and high levels of compatibility.

Each student has different self-confidence, likewise in learning English we will meet children with high self-confidence and some who have low self-confidence. Especially with the learning model that changed from its usual condition after the covid-19 situation attack. Pranoto [11] defines that the attitude of a person who shows that he is not confident, among others, every time he does something important and is full of challenges, is often faced with an attitude of doubt, uncertainty, anxiety, lack of initiative, tends to avoid, easily discouraged, does not dare to appear in front of a crowd or on camera. Their insecurities will always feel inadequate and are afraid of making mistakes. This makes them not know what abilities or potentials they have and will further bury their abilities or potentials.

we will see weaknesses as a natural thing that is owned by every individual because confident individuals will turn their weaknesses into motivation to develop their strengths and will not provide these weaknesses. Self-confidence is the key to self-motivation, you cannot live your life well without self-confidence. Every individual will need confidence every day in various ways, including students in following the learning process $\mathrm{m}$. A good level of selfconfidence facilitates decision-making and paves the way for making friends, building relationships, and helping individuals maintain success. Self-confidence is one aspect of personality that is very important in human life. Ersta [15] said that confident individuals feel confident in their abilities and have realistic expectations, even when their expectations are not met, they remain positive and can accept them.

Besides that, self-confidence can act without hesitation. So big is the function and role of self-confidence in individual life. Without a sense of self-confidence that is firmly planted in the individual's soul, pessimism and inferiority will easily dominate him. Without being equipped with solid self-confidence from an early age, the individual will grow into a weak person. Students who are not confident have a negative self-concept, lack confidence in their skills, this causes them to close themselves to their surroundings. Without self-confidence, students have a risk of failure or less than optimal in doing tasks as teenagers.

Increasing self-confidence here is growing students' confidence to develop their potential without shame and doubt. By providing group counseling so that students are more courageous in showing their abilities in front of their friends, and are not awkward in interacting with other people. Lack of self-confidence is detrimental to students not only through associating with low attitudes but through students considering their choices in different ways. Lack of confidence may require attention to help ensure that students' future choices do not need to be limited. The confidence condition of students is different, some are happy to tell stories, have discussions, but some are the opposite. This can be seen from the symptoms that appear among them, students hesitate when asked to present the results of the discussion in class.

This shows that the attitude of self-confidence in learning is low. Besides students are a little difficult when asked to interact with other students. Furthermore, when the discussion took place there were some students looked doubtful, afraid, and also embarrassed in expressing their opinions or responses in the group discussion. It is in this group discussion that they tend to be 
silent and passive. From the problems encountered by the researchers above, researchers must increase the confidence of students.

\section{Method}

The method used is quantitative research because quantitative methods are called traditional methods after this method has been used for a long time so that it has become a traditional research method. This method is called the quantitative method because the research data is in the form of numbers and the analysis uses statistics. This research was carried out at SD Negeri 4 Katobengke by looking at things related to the problem under study.

The form of research used in this study is the pre-experimental design one group pre-test and post-test design because this study does not use a control group and this design has a pretest before it is given treatment. Thus, the treatment results can be found out more accurately. This research was conducted during the new normal covid-19 pandemic. Methods of data collection in this study using a questionnaire method/questionnaire, interview methods, and observation.

Based on the data collection method, a suitable data collection instrument to increase selfconfidence is a questionnaire sheet. The questionnaire in this study was used to collect data on the responses or responses of students to group counseling of role discussion techniques in increasing students' self-confidence. The questionnaire is a data collection technique that is done by giving a set of questions or written statements to respondents to answer. The questionnaire can be a closed or open question/statement.

\section{Result and Discussion}

The implementation of this study used group counseling services to increase the confidence of students at SD Negeri 4 Katobengke. The aim of handling students who experience low selfesteem in English subjects before and after being given group counseling services. This research was conducted from June to July 2020, according to the schedule agreed upon with the research subject. The results of the researchers were obtained through the distribution of instruments that aim to obtain data on the profile/picture of students 'self-confidence and at the same time with the basis of adjusting the content of group counseling services to increase students' confidence which was then tested to obtain effectiveness. The number of students in this study was 25 students, while in low criteria there were 18 students.

Group counseling services with discussion techniques were held 4 times in one classroom by implementing strict health protocols. The results of providing group counseling services are evaluated by doing a post-test, a post-test is carried out to determine the level of self-confidence of students after doing group counseling that has been given to students who experience low self-confidence. Comparison of the average value before and after group counseling services was provided based on the data obtained, the results of the study can be defined before treatment (pre-test) and after treatment (post-test).

In this group counseling activity, the group leader tries to build group dynamics where the group dynamics play a very important role in increasing the self-confidence of students. Because of inactive group dynamics, students are directly involved in solving problems faced by other members and themselves. The role of group leaders in building group dynamics in group counseling discussion techniques is to ask members to be able to work together and to show 
concern for the needs of their members, group leaders provide clear instructions, direction, and group counseling process, discussion techniques, and always supervise group members during the process. group meetings take place, group leaders encourage members to provoke selfconfidence so that the group counseling process runs smoothly.

\subsection{Results}

The pre-test was carried out to know the initial picture of the condition of self-confidence in learning that was given the treatment. The pre-test was given to 18 class $\mathrm{V}$ students. Table 1 is the results of the pre-test conditions for students' self-confidence.

Table 1. Pre-test results of class V SD Negeri 4 Katobengke

\begin{tabular}{cccc}
\hline No & Code & Pre-test & Criteria \\
\hline 1 & AIF & 42 & Low \\
2 & AA & 40 & Low \\
3 & A & 54 & Low \\
4 & BS & 56 & Low \\
5 & DAP & 52 & Low \\
6 & EMB & 51 & Low \\
7 & FDS & 49 & Low \\
8 & GSG & 52 & Low \\
9 & MAR & 50 & Low \\
10 & MDP & 55 & Low \\
11 & MR & 54 & Low \\
12 & MDA & 37 & Low \\
13 & RMS & 42 & Low \\
14 & SS & 46 & Low \\
15 & SKN & 55 & Low \\
16 & YN & 50 & Low \\
17 & NFT & 43 & Low \\
18 & MS & 58 & Low \\
\hline & & &
\end{tabular}

After the group discussion was ended, the students were invited to fill in the learning discipline instrument as a form of post-test. The posttest implementation at SD Negeri 4 Katobengke can be said to be smooth with the average student being able to provide information about self-confidence after the discussion technique group counseling service with all instrument items being filled according to the filing instructions and this activity is completed on time. The following table are the results of the post-test conditions for students' selfconfidence 
Table 2. Post-test results of class V SD Negeri 4 Katobengke

\begin{tabular}{cccc}
\hline No & Code & Post-test & Criteria \\
\hline 1 & AIF & 72 & Moderate \\
2 & AA & 80 & Moderate \\
3 & A & 84 & Moderate \\
4 & BS & 96 & High \\
5 & DAP & 82 & Moderate \\
6 & EMB & 81 & Moderate \\
7 & FDS & 89 & Moderate \\
8 & GSG & 92 & High \\
9 & MAR & 90 & High \\
10 & MDP & 95 & High \\
11 & MR & 74 & Moderate \\
12 & MDA & 87 & Moderate \\
13 & RMS & 82 & Moderate \\
14 & SS & 86 & Moderate \\
15 & SKN & 85 & Moderate \\
16 & YN & 90 & High \\
17 & NFT & 93 & High \\
18 & MS & 78 & Moderate \\
\hline
\end{tabular}

Based on Table 2 above, that after being given group counseling service treatment there was an increase in group members' confidence, there were 12 students in moderate criteria and 6 students who were high criteria, which at the time before the treatment there were students who had low criteria in self-confidence.

\subsection{Discussion}

Based on the results of the study showed that there was an increase in the confidence of the students, indicating that there was an increase in the self-confidence of grade V students at SD Negeri 4 Katobengke after receiving group counseling services. The results of this study also showed that group counseling services were carried out in 6 meetings and were combined to distribute questionnaires as well, so the next step the author will discuss in-depth the confidence of class V students at SD Negeri 4 Katobengke. Before and after, group counseling services are provided that are linked to theory.

Before the existence of group counseling services (pre-test), students had an average selfconfidence score of 49.22 or a low category, this showed that the students' self-confidence was still low and could still be improved. After the existence of group counseling services, students have an average self-confidence score of 85.33 in the high category. This identifies that there has been an increase in the self-confidence characteristics of students. It was proven after the group counseling service had an increased average score.

This shows that the presence of group counseling can increase positive self-confidence and reduce negative self-confidence, thus it can be concluded that students' self-confidence before and after receiving group counseling discussion techniques is different and has a significant increase. Group counseling services are effective in increasing students' self-confidence because in the implementation of group counseling activities students as group members will jointly create group dynamics that can be made appropriate to develop and increase self-confidence. Group members will have the same right to discuss a problem topic, also be able to train 
students' abilities both the ability to dare to express opinions in forums and to train students to be trained to interact socially in groups.

Group counseling services are effective in increasing students' confidence. Because in the implementation of group counseling it does not aim to solve problems but also to solve problems and to develop personal character. Dinkmeyer and Murno mentioned three kinds of discussion objectives, namely: 1) to develop towards oneself, 2) to develop self-awareness, 3) to develop new views on human relationships. If that goal is realized, it can develop students' confidence. Therefore, self-confidence is needed by someone to be used as a reference for how someone lives and demands someone's needs. However, a person's self-confidence is not innate but is formed through the learning process from the time a person grows from childhood to adulthood.

The success of group counseling at SD Negeri 4 Katobengke is running smoothly as seen from the effectiveness of the members in following the group counseling process. With group counseling, it can help students to manifest themselves as whole human beings to reach the world and the hereafter. So that researchers feel it is appropriate to use it as a form of guidance and counseling services to be provided to students who have low self-confidence. Students who have group counseling activities can directly practice creating group dynamics, namely, practice speaking, responding, listening, and being considerate in a group atmosphere. Confidence in a person is not innate but is formed through the learning process from the time a person grows from childhood to adulthood.

Although group counseling can increase students' self-confidence, this study found several obstacles, at first, the group leader had difficulty building group member activeness because all group members still looked shy and hesitant and this was the first time they attended group counseling. However, this was resolved by group members with introductions and games. This introduction aims to make all group members know and be familiar with each other. In addition, games are also carried out to make the atmosphere more relaxed and comfortable so that it doesn't look stiff and group members feel happy. Also, this limitation is related to the time to carry out the process in the group counseling services carried out. the group counseling process runs smoothly for approximately 45 minutes in each meeting.

\section{Conclusion}

Group counseling services with influential discussion techniques to increase selfconfidence in grade V SD Negeri 4 Katobengke for the 2019/2020 academic year. This is indicated by an increase in self-confidence scores in 18 students after being given treatment group counseling services with discussion techniques.

\section{Acknowledgments}

This research was supported by the University of Muhammadiyah Buton. We thank Mrs. Wa Ode Al Zarliani our rector for supporting us, and SD Negeri 4 Katobengke as a place to do this research. 


\section{References}

[1] Albertus, Doni Koesoema. (2007). Pendidikan Karakter, Strategi Mendidik Anak di Zaman

[2] Borg and Gall. 1983. Qualitative Research, Techniques and Procedures For Developing Grounded

[3] Ali gufron, Teori-teori psikologi (Yogyakarta : Ar-ruzz Media, 2011).

[4] Baharun Hasan and Rohmatul Ummah," strengthening Student' Character in akhlaq subject Through Problem Based Learning Model, "Tadris Jurnal keguruan dan ilmu tarbiyah 3, no. 1(2018):21

[5] Chadidjah HA dan Dian arina S, "keefektifan layanan bimbingan kelompok dengan metode diskusi untuk mengembangkan konsep diri”. Program studi bimbingan dan konseling, FKIP Universitas sebelas Maret. Corey Gerald, teori dan praktik dan psikotrapi, Bandung : PT.Refika Aditam. Dapertemen Agama RI, Al-Qur'an dan Terjemah, Bandung : CV. Diponogoro.

[6] Dewa ketut sukandi, pengantar pelaksanaan program bimbingan dan konseling di sekolah, Jakarta: rinek cifta, 2010).

[7] Edi irawan, "efektifitas teknik bimbingan kelompok untuk meninngkatkan konsep diri remaja (Studi Pre-experimen pada siswa kelas X SMK Yopena grading rejo lampung). Junal Bimbingan dan Konseling (PSIKOPEDAGOGIA), Vol. II, No , 1,2013 program studi bimbingan konseling FKIP AUD.

[8] Eko Putra Widoyo, penilitian hasil pembelajaran di sekolah, Yogyakarta:Pustaka Pelajar, 2014.

[9] Ersta k lydia, sekilas tentang percaya diri pada remaja, jurnal ilmiah widya wacana, vol. 8 nomer 2 (mei 2012),

[10] Fransiska, slamet f, \& iis i, layanan bimbingan kelompok dengan teknik diskusi untuk meningkatkan kemampuan komunikasi interpersonal siswa kelas viii smp negeri 7 singkawang tahun ajaran 2014/2015, jurnal bimbingan konseling indonesia, volume 2 nomor 1 2017, p-issn: 2477-5916 eissn: 2477-8370.

[11] Hadi pranoto, upaya meningkatkan percaya diri siswa mealui layanan bimbingan kelompok di sma negeri 1 sungkai utara ampung utara, jurnal lentera pendidikan lppm um metro vol. 1. no. 1, juni 2016 issn: $2527-8436$.

[12] Imro'atum, keefektifitas layanan konselingkelompokuntuk meningkatkan kepercayaan diri siswa menengah pertama, jurnal kajian bimbingan dan konseling. issn 2548-4311. tersedia di : um.ac.id/index.php/jkbk/article/view/65.

[13] Jarkawi, penyuluhan tentang cara meningkatkan kepercayaan diri siswa dengan Fun Game pada musyawarah guru bimbingan dan konseling Mts kota banjar masin, Jurnal Al-Ikhlas. Vol 2 No 1, oktober 2016. ISSN: 2461-0992.

[14] Lauster, Tes kepribadian (ahli bahasa) : H.D Gulo, Edisi Bahasa indonesia, Cetak Ke XIII (Jakarta : Bumi Aksar, 2002).

[15] Lydia Ersta, Sekilas Tentang Rasa Percaya Diri Pada Remaja,, jurnal ilmiah widya wacana. Vol 8 nomer. 2 mei 2012. ISSN: 1907-5928.

[16] Maharani Laila, Mansur Muhammad , Efektivitas Konseling Puisi Sebagai Media Bimbingan Dan Konseling Dalam Meningkatkan Rasa Percaya Diri Peserta Didik Kelas VII Smpn 24 Bandar Lampung Tahun Ajaran 2015/2016. Jurnal Bimbingan dan Konseling, p-ISSN 2089-9955, e-ISSN 2355-8539.

[17] Maharani Laila, Ningsih Tika, layanan konseling kelompok teknik asertive training dalam menangani konsep diri negatif pada peserta didik. Jurnal Bimbingan Konseling • p-ISSN 2089-9955, e-ISSN 2355-8539.

[18] Masya Hardiansyah, Rohyan, penggunakan Konseling Kelompok dalam meningkatkan rasa percaya diri peserta didik kelas VII Smp wiyata karya natar kabupaten lampung selatan. Jurnal Bimbingan Konseling. Vol 3, No 2 (2016). p-ISSN 2089-9955, e-ISSN 2355-8539.

[19] Muslihin, Pengaruh layanan bimbingan kelompok terhadap meningkatkan rasa percaya diri siswa, Jurnal Ilmu pendidikan bimbingan dan konseling. Vol. 2 No 1, Oktober 2014.

[20] Prayitno dan Erman Amti, 2009. Layanan Bimbingan Kelompok dan Konseling Kelonpok. Padang: Universitas Negeri Padang.

[21] Prayitno, dasar-dasar bimbingan dan konseling (Jakarta : pt rineka cifta, 2004). 
[22] Rahayuningdyah Endang, upaya meningkatkan kepercayaan diri melalui layanan konseling kelompok pada siswa kelas VIII D di Smp Negeri 3 Ngrambe, Jurnal Bimbingan konseling. Vol 1 No 2. Seftember 2016. ISSN: 2503-2542.

[23] Richard Sheldrake, students' intention towards studying science at upper-secondary school: the differential effects of under-confidence and over-confidence, international journal of science Education (2016), ISSN: 0950-0693.

[24] Rifda El fiah, Ice anggralisa, Efekitvitas layanan konseling kelompok dengan pendekatan realita untuk mengatasi kesulitan komunikasi interpersonal peserta didik kelas x man krui lampung barat t.p 2015/2016. Jurnal Bimbingan dan Konseling, Vol 3, No 1 (2016). p-ISSN 2089-9955, e-ISSN 23558539 ,

[25] Sinar Juliyana Putri, Pengaruh konseling kelompok dengan teknik assertive training terhadap percaya diri peserta didik kelas viii b di mts muhammadiyah sukarame bandar lampung tahun ajaran $2017 / 2018$.

[26] Siska, Sudardjo \& Esti Hayu purnama ningsih, kepercayaan diri dan kecemasan komunikasi interpersonal pada mahasiswa, Jurnal Psikologi 2003, No. 2, 67- 71, ISSN : 0215-8884

[27] Sri marjati, upaya meningkatkan rasa percaya diri melalui konseling kelompok bagi siswa $\mathrm{x}$ ips 6 sma 2 bae kudus tahun pelajaran 2014/2015. jurnal konseling gujigat. vol. 1 no. 2 tahun 2015 ISSN :2460-118.

[28] Sugiyono, metode penelitian kuantitatif kualitatif dan $r$ \& d, (Bandung : alfabeta), 2015.

[29] Tohirin, bimbingan dan konseling sekolah dan madrasah, (jakarta: pt rajagrafindo persada 2009) 